\begin{tabular}{|cc}
\hline K I N E R J A 15 (2), 2018 57-67 \\
heB UNMUL.
\end{tabular}

\title{
Determinan Kinerja Keuangan Perbankan Syariah
}

\author{
Mukti Prasaja \\ Sekolah Tinggi Ilmu Ekonomi, Bojonegoro. \\ Email: prasojomuktis2@gmail.com
}

\begin{abstract}
Abstrak
Industri perbankan syariah adalah salah satu penggerak potensi pertumbuhan suatu negara. Ini ditandai dengan peningkatan yang signifikan. Namun, jumlah perbankan syariah di Indonesia mengalami peningkatan, selama periode 2014-2016. Tujuan penelitian ini adalah kinerja keuangan pada perbankan syariah dengan variabel pembiayaan, efisiensi operasional, prinsip kecukupan modal, pembagian keuntungan dan kontribusi sosial. Objek penelitian adalah perbankan syariah yang telah diterbitkan oleh OJK 2011-2016 tahun. Periode pemilihan tahun itu agar dapat memberikan gambaran lengkap dan istilah yang terkait dengan kinerja perbankan syariah. Hasil penelitian ini menunjukkan pembiayaan dan kecukupan modal tidak memiliki pengaruh signifikan terhadap kinerja keuangan. Sementara untuk efisiensi operasional dan bagi hasil untuk hasilnya berdampak pada kinerja keuangan. Adapun pengaruh bolak antara kinerja keuangan dan kontribusi sosial satu sama lain.
\end{abstract}

Kata Kunci: rasio-keuangan; kontribusi sosial; kinerja keuangan bank islam

\section{Determinants of Sharia Banking Financial Performance}

\begin{abstract}
Sharia banking industry being one of the drivers of growth potential for a country. It is characterized by the development of Islamic banks in the world have experienced a significant increase. However, the published statistics from the growth of the financial performance during the period of 2014-2016 has decreased while the number of Islamic banking in Indonesia experienced an increase. The purpose of this research is to know the determinants of financial performance on Islamic banking with variable financing, operational efficiency, principles for capital adequacy, profit sharing and social contribution. The object of the research is Islamic banking that already published by OJK 2011 2016 year. The election period that year in order to be able to give a complete picture and long term related to the performance of Islamic banking. The results of this study indicate the financing and capital adequacy has no significant influence on performance of finance. Meanwhile for operational efficiency and profit sharing for the results to have an impact on financial performance. As for the influence of alternating between financial performance with social contributions influence each other.
\end{abstract}

Keywords: ratio-financial; social contributions; the financial performance of islamic banks 


\section{PENDAHULUAN}

Perbankan menjadi salah satu bagian yang penting dalam menyediakan intermediasi keuangan dan investasi yang produktif bagi pertumbuhan suatu negara. Untuk mengimplementasikan kedua hal itu terdapat sistem dual bank system, yakni dengan sistem konvensional dan syariah. Hal ini terbukti dengan perkembangan Islam semakin besar dengan berdirinyaIslamic Development Bank (IDB) pada tahun 1975 yang pusatnya di Jeddah, kemudian diikuti dengan pendirian perbankan Islam di seluruh dunia termasuk di kawasan Eropa (Falikhatun dan Umar, 2012). Perkembangan tersebut juga terjadi di Indonesia, jumlah bank syariah bertambah banyak dari tahun ke tahun. Mulai dari Bank Muamalat Indonesia, kemudian diterbitkannya ketentuan dari Bank Indonesia (BI) yang mengijinkan untuk bank konvensional mendirinkan Unit Usaha Syariah (UUS). Data Otoritas Jasa Keuangan/OJK (2016) menyebutkan pada tahun 2015 terdiri 12 (BUS) Bank Umum Syariah dan 22 (UUS) Unit Usaha Syariah. Kemudian bertambah tahun 2016 menjadi 13 (BUS) Bank Umum Syariah dan 21 (UUS) Unit Usaha Syariah.

Akan tetapi dari data yang dipublikasikan oleh Islamic Financial Service Board/IFSB (2016) menyebutkan trend rata-rata pertumbuhan Bank Islam secara global menunjukkan penurunan yang fluktuatif dari tahun 2010 hingga 2014 dilihat dari aset, pembiayaan dan depositnya. Hal tersebut juga dikuatkan dengan publikasi dari OJK terkait rasio-rasio keuangan yang di ukur dengan ROE, NOM dan ROA kinerja keuangan perbankan syariah mengalami penurunan dari tahun 2013-2016. Adapun untuk rasio-rasio yang mempengaruhi kinerja keuangan adalah BOPO, FDR, CAR berdasarkan penelitianpenelitian sebelumnya (Setiawan, 2009), (Menicucci dan Paolucci, 2015). Berkaitan dengan kinerja perbankan syariah, ternyata tidak hanya dipengaruhi oleh indikator-indikator keuangan saja. Hal itu dinyatakan dalam penelitian Mallin, Faraq, Yong, Kean. (2014) terkait Corporate Social Responsibility dan Kinerja Keuangan di Bank Islam yang menemukan adanya hubungan positif antara keduanya. Kemudian Rokhmana (2015) juga melakukan penelitian terkait pengaruh kinerja keuangan terhadap kinerja sosial pada bank syariah Indonesia pada tahun 2010-2014.

Baik ROA dan ROE secara luas digunakan untuk pengukuran kinerja bank dan keseimbangan pertumbuhannya (Mallin, dkk. 2014). Bank Indonesia (BI) selaku regulator dalam perbankan di Indonesia mengklasifikasikan kinerja di perbankan syariah yang mana aset memiliki proporsi yang paling besar dengan 50\%. Kemudian dari Data Otoritas Jasa Keuangan (2016) juga menyebutkan bahwasannya NOM merupakan ukuran rentabilitas untuk perbankan syariah di Indonesia. Selain itu NOM juga digunakan dalam menentukan tingkat kesehatan finansial di perbankan syariah (Falikhatun dan Umar, 2012). Menurut Stiawan (2009) karakteristik bank dapat ditentukan dengan mengetahui angka rasio-rasio keuangannya. Adapun rasio dalam penelitian tersebut ialah rasio efisiensi (BOPO), rasio permodalan (CAR), serta rasio pembiayaan (FDR). Rasio-rasio tersebut berhubungan dengan kinerja keuangan di perbankan konvensional maupun syariah. Kemudian Falikhatun dan Umar (2012) melakukan penelitian tentang Ketaatan Pada Prinsip Syariah yang diukur dengan Profit Sharing Ratio (PFR) dan Kesehatan Finansial diukur dengan NOM. Selain itu Rokhmana (2015) mengkaji kinerjakinerja sosial yang mempengaruhi kinerja di perbankan syariah.

Pada penelitian-penelitian sebelumnya untuk hasil penelitiann masih terdapat perbedaan dari faktor-faktor yang mempengaruhi kinerja keuangan bank syariah. Stiawan (2009) dalam penelitiannya terkait faktor-faktor finansial yang berpengaruh pada profitabilitas perbankan syariah di Indonesia menemukan CAR memiliki pengaruh signifikan pada ROA perbankan syariah Indonesia. Akan tetapi hal ini bertentangan dengan penelitian oleh Syaichu dan Wibowo (2013) tentang analisis CAR, BOPO, suku bunga, inflasi dan NPF yang mana justru menemukan variabel CAR tidak memiliki pengaruh terhadap profitabilitas dalam perbankah syariah. Selanjutnya Eka (2014) juga melakukan penelitian berkaitan pengaruh Net Operating Margin (NOM), Financing to Deposit Ratio (FDR), Credit Risk pada kinerja keuangan perbankan syariah yang diukur dengan ROE dan menemukan adanya pengaruh yang signifikan antara kedua variabel tersebut. Penelitian tersebut dikuatkan oleh Menicucci dan Paolocci (2015)yang meneliti determinan profitabilitas di Perbankan Eropa dan hasilnya menemukan deposit berpengaruh positif dan signifikan pada ROA dan ROE di perbankan Eropa periode 2009-2013.

Pada penelitian Imam (2007) terkait faktor-faktor finansial yang mempengaruhi pada profitabilitas Bank Syariah Mandiri tahun 2004-2006 menemukan bahwa variabel BOPO berhubungan positif dan signifikan pada profitabilitas Bank Syariah Mandiri. Namun demikian hal tersebutberbeda dalampenelitian yang dilakukan Stiawan (2009) yang justru menemukanBOPO memiliki pengaruh 
signifikan negative pada profitabilitas bank syariah. Selain faktor-faktor tersebut, ada faktor lain yang memberikan pengaruh terhadap kinerja keuangan perbankan syariah. Faktor-faktor tersebut diantaranya Profit Sharing Ratio yang memberikan pengaruh terhadap kesehatan finansial bank syariah (Falikhatun dan Umar, 2012). Selain itu juga ada kontribusi sosial terhadap kinerja keuangan yang diteliti oleh Setiawan (2009). Dalam penelitian ini menggunakan ROA dan NOM sebagai ukuran kinerja keuangan. Hal ini dikarenakan kedua pengukuran tersebut menggunakan aset dalam perhitungannya yang mana memiliki prosentase yang tinggi berdasarkan Surat Edaran BI N0. 9/24/ Tahun 2007 tentang Penilaian Tingkat Kesehatan Bank Umum yang didasarkan Sistem Syariah. Penelitian ini dilaksanakan untuk menganalisis faktor-faktor yang mempengaruhi kinerja keuangan di bank syariah. Pada penelitianpenelitian sebelumnya masih memisahkan antara rasio keuangan, kepatuhan syariah dan kinerja sosial. Oleh karena itu dalam penelitian ini akan menggabungkan faktor-faktor tersebut dan diharapkan mendapatkan hasil yang lebih komprehensif.

\section{Kajian Putaka}

\section{Stewardship Theory}

Teori ini diungkapkan oleh Donalson dan Davis (1991) yang menjelaskan bagaimana para eksekutif pada suatu perusahaan bertindak sebagai pelayan yang termotivasi untuk menjalankan perusahaan dengan cara terbaik pada prinsipalnya. Para manajer tidak hanya berfokus pada kepentingan individu saja tetapi lebih diarahkan untuk mencapai hasil utama mereka yakni untuk kepentingan perusahaan dan prinsipal. Dalam hal ini steward diartikan sebagai pengelola, di mana dalam suatu perusahaan memiliki wewenang dalam menjalankan operasional kegiatan sehari-hari dari perencanaan permodalan dan produk-produk ataupun jasa yang dihasilkan. Steward yang menjalankan wewenang dengan baik akan meningkatkan kinerja di suatu perusahaan, sehingga akan mampu untuk memenuhi harapan dari para prinsipal.

Untuk melihat efisiensi operasional pada suatu perusahaan khususnya perbankan syariah dapat dilihat melalui rasio Biaya dan pendapatan operasional. Sedangkan pembiayaan kepada pihak ketiga dalam operasional perbankan syariah dapat dilihat melalui Financing to Deposit Ratio yang dipublikasikan pada laporan keuangan perusahaan. Kemudian untuk mendukung kegiatan operasional di perbankan syariah memerlukan pengalokasian dana yang cukup dan sesuai agar terhindar dari kesulitan ekonomi. Permodalan tersebut dapat dianalisis melalui rasio keuangan Capital Adequacy Ratio di mana mencerminkan permodalan yang wajib disediakan oleh perbankan untuk mengurangi terjadinya risiko investasi.

\section{Shariah Enterprise Theory}

Shariah Enterprise Theory (SET) adalah suatu teori yang mengimplementasikan kaedah dalam Islam untuk menghasilkan teori transendetal dan lebih humanis. Kemudian Shariah Enterprise Theory tidak hanya peduli terhadap kepentingan individu, tetapi juga memperhatikan pihak-pihak lainnya yang berhubungan dengan perusahaan. Menurut Triwuyono (2007) Shariah Enterprise Theory meliputi stakeholder yakni Allah, manusia dan alam. Dalam teori ini stakeholders mencakup direct participants dan inderect participants.

Selain itu menurut Isgiyarta (2009), posisi perusahaan dalam akuntansi Islam benar-benar terpisah dari pendiri dan pemiliknya. Dalam produk yang dihasilkan atau pendapatan yang didapatkan didasarkan pada Al-Qur'an, Al Hadist, ijmak dan qiyas. Perbankan syariah memiliki produk-produk dan jasa-jasa yang dihasilkannya harus sesuai dengan hukum-hukum Islami. Prinsip bagi hasil merupakan jenis pembiyaan yang sesuai dengan syariat Islam. Prinsip bagi hasil ini dihitung dengan Profit Sharing Ratio yang mana menunjukkan seberapa besar pembiayaan mudharabah dan musyarakah (bagi hasil) dibagi dengan total pembiyaan.

\section{Kinerja Keuangan Bank Syariah}

Ketika suatu perusahaan memiliki kinerja bagus, maka akan terjamin kelangsungannya dikarenakan memiliki kepercayaan dari publik, sehingga publik merasa nyaman ketika akan berinvestasi pada perusahaan yang dituju (Eka, 2014). Dalam hal ini kinerja suatu perusahaan dapat digunakan dengan melihat ukuran non keuangan dan keuangan. Ketika suatu perusahaan memiliki kinerja bagus, maka akan terjamin kelangsungannya dikarenakan memiliki kepercayaan dari publik, sehingga publik merasa nyaman ketika akan berinvestasi pada perusahaan yang dituju (Eka, 2014). Dalam hal ini kinerja suatu perusahaan dapat digunakan dengan melihat ukuran non keuangan dan keuangan. 
Menurut Mallin, dkk. (2014) Return on Equity dan Return on Aset seringkali dipakai untuk pengukuran kinerja keuangan bank dan pertumbuhan secara berkelanjutan. Selanjutnya pada Surat Edaran BI N0. 9/24/ Tahun 2007 tentang Penilaian Tingkat Kesehatan Bank Umum yang didasarkan Sistem Syariah, pengukurannyamenggunakan CAMELS untuk mengetahui kondisi dan kinerja dari bank dengan prosentase untuk faktor kualitas aset (50\%), permodalan (25\%), likuiditas (10\%), rentabilitas (10\%) dan sensitivitas atas resiko pasar (5\%). Oleh karena itu dengan penjelasan-penjelasan tersebut pada penelitian ini akan berfokus pengukuran kinerja keuangan dengan proksi ROA dan NOM dalam pengujian variabel dependennya, dikarenakan dalam pelaksanaan industri perbankan syariah ini untuk prosentase labanya sebagian besar dari aset yang dimiliki dan permodalannya dengan surat berharga.

\section{Return on Aset (ROA)}

ROA adalah tingkat kemampuan modal dari perusahaan untuk investasi pada segala aset yang dimiliki perusahaan dalam rangka untuk mendapatkan laba. Menurut Stiawan (2009) ROA fokus tingkat kemampuan perusahaan untuk menghasilkanearning pada operasional perusahaan. Ketika laba yang diperoleh suatu perusahaan meningkat, hal ini mengakibatkan ROAnya juga tingi. Oleh karenanya hal itu berarti perusahaan semakin baik dalam menjalankan aset perusahaan untuk mendapatkan keuntungan yang diharapkan. Adapun untuk perumusan ROA dapat dijelaskan sebagai berikut:

ROA $=\frac{\text { Laba bersih }}{\text { Total } \text { Aset }}$

Menurut Dendawijaya dalam Stiawan (2009) ROA menjadi pengukuran untuk profitabilitas di bank yang dihitung dengan aset. Oleh karena itu aset dalam perbankan syariah di Indonesia sangat potensial untuk terjadi peningkatan.

\section{Pembiayaan}

Pada bank-bank syariah tidak menggunakan pengertian kredit (loan) namum lebih diartikan pembiayaan (financing) (Antonio, 2001). Beberapa penelitian yang telah dilakukan lebih banyak mengarah pada Loan to Deposit Ratio (LDR). Istilah LDR itu sendiri pada bank-bank syariah sering disebut dengan Financing to Deposit Ratio (FDR). FDR ialah pengukuran yang memberitahukan bagaimana pembiayaan yang produktif dapat diberikan oleh bank guna menghasilkan keuntungan atau profit dibanding dengan total pihak ketiga. Rasio Pembiayaan diukur dengan FDR dan dapat di rumuskan melalui formula sebagai berikut:

$$
\text { FDR }=\frac{\text { Jumlah pembiayaan yang disalurkan }}{\text { Total Deposit }} \times 100 \%
$$

Para praktisi di perbankan telah bersepakat batasan aman LDR pada tingkatan 80\%, akan tetapi batasan toleransinya sekitar $85 \%-100 \%$.

\section{Efisiensi Operasional}

Efisiensi pada operasional perusahaan akan mempengaruhi suatu kinerjanya bertambah baik. Menurut Dendawijaya dalam Stiawan (2009) rasio efisiensi operasional (BOPO) fungsinyauntuk mengetahui tingkatan efisiensi dan bagaimana kapasitas bank pada kegiatan operasional yang dijalankan. Efisiensi ini menjelaskan perbandingan antara biaya operasi dengan pendapatan operasi kegiatan perusahaan. Adapun efisiensi ini dapat diukur dengan BOPO yang perumusannnya sebagai berikut :

$$
\mathrm{BOPO}=\frac{\text { Biaya Operasional }}{\text { Pendapatan Operasional }}
$$

Ketika BOPO semakin rendah mengindikasikan bank dalam melaksanakan operasional semakin efisien. Bank yang baik memiliki angka BOPO tidak lebih dari 1, sebaliknya apabila BOPOnya lebih dari 1 berarti bank kurang baik.

\section{Kecukupan Permodalan}

Pada perbankan syariah kecukupan permodalan dapat dilihat dari angka Capital Adequacy Ratio (CAR). Stiawan (2009) mengungkapan CAR ialah bagaimana kapasitas bank dalam menyiapkan dana yang digunakan dalam mengembangkan usaha dan menyimpan dana untuk mengatasi kerugian atas operasi di perbankan syariah. Kalkulasi CAR dilandasi pada penanaman yang mengandung risiko, kemudian untuk permodalan yang disediakan sebesar prosentase tertentu terhadap jumlah 
penanamannya. Adapun untuk permodalan ini diukur dengan CAR dan dapat diformulakan sebagai berikut :

$\mathrm{CAR}=\frac{\text { Modal Sendiri }}{\mathrm{ATMR}} \times 100 \%$

Dalam Peraturan Bank Indonesia Nomor 10/15/PBI/2008 pasal 2 ayat 1 tentang Kewajiban dalam Penyediaan Modal Minimum dari Bank adalah tercantum bank memiliki kewajiban modal dengan $8 \%$ atas ATMR (aset tertimbang menurut resiko).

\section{Kontribusi Sosial Perbankan Syariah}

Perbankan Syariah dalam melaksanakan kegiatan operasionalnya tidak hanya berfokus dalam fungsi bisnis (profitabilitas) saja, tetapi juga fungsi sosial menjadi karakteristik utama yang dimiliki bank syariah juga. Menurut Rokhmana (2015) kegiatan promosi bank syariah pun tidak semata-mata bertujuan komersil, namun menunjukkan peran bank syariah dalam edukasi masyarakat tentang keuangan dan perbankan syariah. Dalam UU No. 21 Tahun 2008 terkait Perbankan Syariah, fungsi sosial ini diperjelas dalam pasal ke 4 yang menyatakan bahwasannya selain menjalankan fungsinya untuk menyalurkan dan menghimpun dana dari masyarakat, Bank Umum Syariah (BUS) dan Unit Usaha Syariah (UUS) bisa melaksanakan fungsi sosial sebagai lembaga bait al-mal. Fungsi sosial bank syariah tersebut sesuai dengan teori yang terdapat pada Corporate Social Responsibility (CSR), yang mana memberikan kemanfaatan bagi shareholders (pemegang saham) dan stakeholders (pegawai, komunitas setempat, pemerintah, konsumen dan lingkungan).

Setiawan (2009) membagi beberapa acuan dan tolak ukur yang bisa digunakan untuk mengukur kontribusi sosial dalam perbankan syariah. Tolak ukur tersebut diantaranya untuk mengukur Peningkatan Kapasitas SDI, Kontribusi Kepada Masyarakat (KKM), Kontribusi Pembangunan Ekonomi (KPE), Kontribusi Untuk Stakeholder (KUS), Distribusi Pembangunan Ekonomi (DPE) dan Riset (PKSR). Ukuran-ukuran ini diklasifikasikan menjadi beberapa rasio dan ditujukan ke pihak-pihak tertentu sesuai klasifikasi yang telah ditentukan.

\section{Prinsip Bagi Hasil}

Pada prinsip bagi hasil ini menjelaskan konsep musyarakah (joint venture profit sharing) dan mudharabah (trustee profit sharing) di mana pemilik dana dan pengelola dana untuk manfaat dan kerugiannya sama-sama tahu (Ascarya, 2007). Prinsip bagi hasil ini dapat di ukur dengan Profit Sharing Ratio. Hameed, dkk (2004) mengatakan indeks kepatuhan syariah dengan profit sharing ratio pada Bank Islam sangat penting untuk meningkatkan tujuan eksistensi dari perusahaan. Oleh karena itu dengan adanya rasio bagi hasil tersebut dapat mengambarkan trend peningkatan, penurunan atau tidak berubah atas pembiayaan syariah dari Bank Islam. Untuk perumusan prinsip bagi hasil ini adalah

$\mathrm{PFR}=\frac{\text { Mudarabah }+ \text { Musyarakah }}{\text { Total financing }}$

\section{Net Operating Margin (NOM)}

Rasio ini termasuk rasio rentabilitas untuk melihat kemampuan dari aset produktif untuk memperoleh laba pada perbankan syariah. Junita (2015) menyatakan rasio NOM juga dapat dipandang dalam dua perspektif berkaitan dengan keadaan bank syariah dalam operasional sehari-hari. Perspektif yang pertama adalah dipandang dari sisi kompetitif pada bank yakni berkaitan dengan jumlah perbankan syariah yang semakin banyak menyebabkan saling berlomba satu sama lain untuk menghimpun dana dari masyarakat. Perspektif kedua dari segi efisiensi bank, yang mana semakin tinggi biaya atas pemeliharaan aset produktif yang digunakan. Namun hal ini terjadi ketika investasi dalam perbankan syariah rendah sehingga kegiatan ekonominya menjadi rendah juga.

$\mathrm{NOM}=\frac{\text { Pendapatan Operasional }}{\text { Rata-rata Aset } \text { Produktif }}$ 


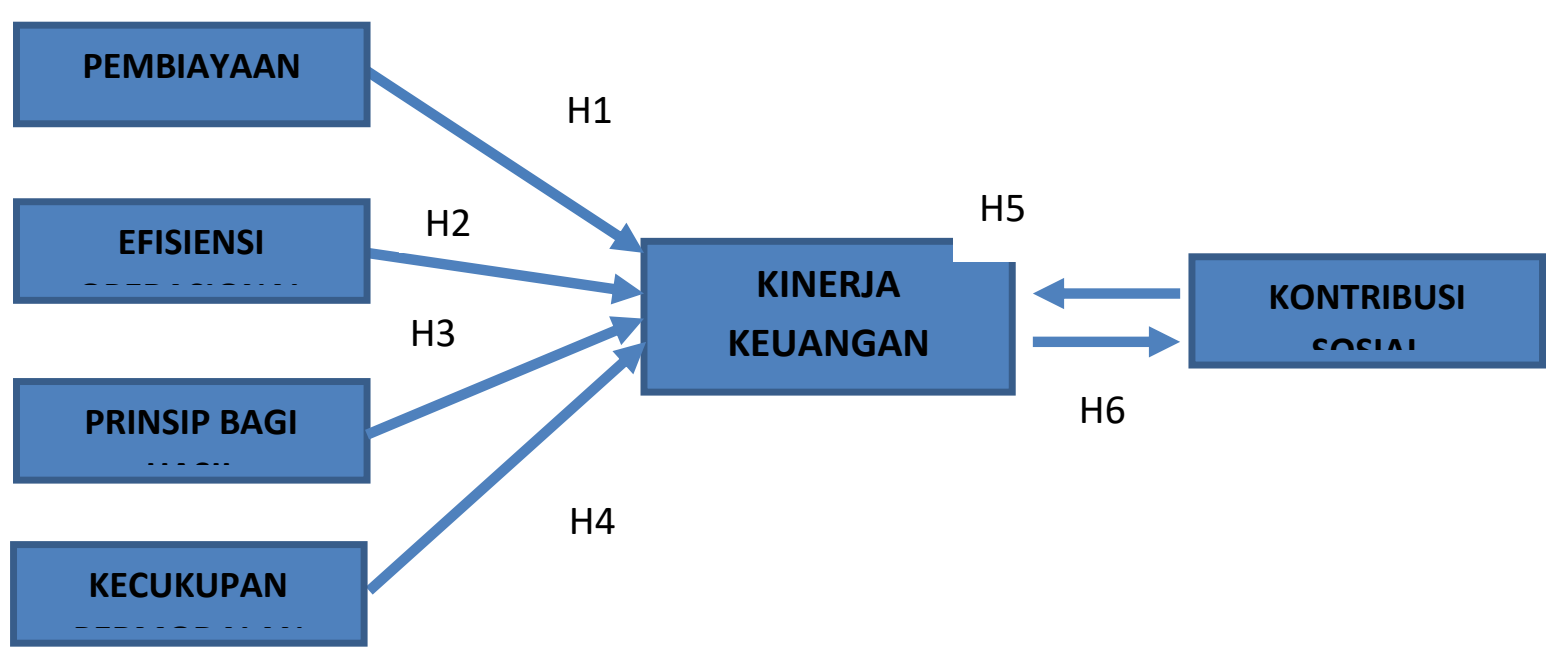

Gambar 1. Model Penelitian

Sumber: Dikembangkan untuk penelitian (2017)

\section{METODE}

\section{Desain Penelitian}

Penelitian ini ialah bentuk penelitian kuantitatif. Metode kuantitatif ini didasarkan pada pendeskripsian faktor-faktor yang berhubungan dengan yang dimaksudkan sebagai pendukung. Tipe investigasinya menggunakan hubungan kausal, yakni menjelaskan pengaruh sebab akibat antara variabel dependen dan variabel independen. Untuk variabel independen terdiri dari Kinerja Keuangan dan Kontribusi Sosial, sementara itu variabel dependennya adalah Pembiayaan, efisiensi operasional, kecukupan modal, dan prinsip bagi hasil.

\section{Populasi dan Sampel}

Populasi yang dipakai pada penelitian ini ialah Bank Umum Syariah yang telah go public dipublikasikan oleh OJK di Indonesia pada periode 2012-2016. Pemilihan periodesasi penelitian tersebut agar mampu memberikan gambaran secara jangka panjang dan lengkap berkaitan kinerja di perbankan syariah. Pada penelitian-penelitian sebelumnya periodesasi penelitian rata-rata 2-3 tahun saja sehingga belum mencerminkan kinerjanya secara lebih komprehensif

\section{Teknik Analisis Data}

Pada penelitian ini menggunakan alat bantu analisis statistik regresi berganda bertahap (two stage least square). dengan alat bantu analisis statistik regresi berganda bertahap (two stage least square). Ghozali (2006) menjelaskan keakuratan persamaan regresi untuk memperkirakan angka sebenarnya dengan Goodness of fit. Untuk perhitungan statistiknya menggunakan uji asumsi klasik dengan uji normalitas, multikolinieritas dan heterokedastisitas. Selain itu juga akan diujikan uji $t$ dan $\mathrm{f}$ untuk melihat pengaruh secara parsial dan serentak dari masing-masing variabel.

\section{HASIL DAN PEMBAHASAN}

\section{Statistik Deskriptif}

Tabel 1. Statistik Deskriptif

\begin{tabular}{cccccc}
\hline Descriptive Statistic & \multicolumn{1}{c}{ N } & Minimum & Maximum & Mean & Std. Deviation \\
\hline ROA & 189 & $-7,77$ & 8,98 & 1,09 & 1,82 \\
NOM & 189 & $-11,64$ & 33,29 & 4,68 & 5,01 \\
FDR & 189 & 46,08 & 161,88 & 93,98 & 13,92 \\
BOPO & 189 & 50,76 & 162,43 & 91,19 & 14,2 \\
CAR & 189 & 9,5 & 59,72 & 19,51 & 8,71 \\
PFR & 189 & 0,33 & 42,61 & 6,77 & 4,53 \\
Kontribusi Sosial & 189 & 0,017 & 0,67 & 0,29 & 0,13 \\
\hline
\end{tabular}

Sumber: Hasil Pengolahan Data Sekunder, 2017 
Berdasarkan tabel statistik deskriptif di atas, ROA dan NOM nilai mean lebih kecil dari standart deviasi hal ini berarti pada variabel ini sebaran datanya memiliki jarak yang besar antara mean setiap unit data dengan mean hitung, sehingga datanya memiliki kecenderungan yang berbeda satu sama lain. Sedangkan untuk FDR, BOPO, CAR, PFR dan Kontribusi Sosial nilai mean lebih besar dari standart deviasi yang mana berarti datanya memiliki kecenderungan angka yang hampir sama satu sama lainnya.

\section{Uji Asumsi Klasik}

Pada penelitian ini menggunakan uji normalitas, heterokedastisitas dan multikolinieritas. Adapun untuk hasil uji asumsi klasiknya sebagai berikut

Tabel 2. Uji Kolmogorov-Smirnov

\begin{tabular}{lll}
\hline & & Ustandardized Residual \\
\hline $\mathrm{N}$ & & 189 \\
Normal Parameters & Mean & 0,00000000 \\
& Std. Deviation & 0,96178183 \\
Most Extreme Differences & Absolute & 0,064 \\
& Positive & 0,052 \\
Test Statistic & Negative & $-0,064$ \\
Asymp. Sig. (2-tailed) & & 0,064 \\
\hline
\end{tabular}

Sumber: Hasil Pengolahan Data Sekunder, 2017

Nilai signifikansi lebih dari 0,05 tersebut mengindikasikan data terdistribusi normal.

Tabel 3. Uji Multikolinieritas

\begin{tabular}{lllll}
\hline Model & & \multicolumn{2}{l}{ Collinearity Statistic } & Keterangan \\
\cline { 3 - 4 } & & Tolerance & VIF & \\
\hline 1. & (Constant) & 0,754 & 1,326 & Tidak Ada \\
& FDR & 0,813 & 1,230 & Tidak Ada \\
& BOPO & 0,936 & 1,069 & Tidak Ada \\
& Profit_Sharing & 0,720 & 1,389 & Tidak Ada \\
& CAR & 0,815 & 1,227 & Tidak Ada \\
\hline
\end{tabular}

Sumber: Hasil Pengolahan Data Sekunder, 2017

Pada tabel 3 tersebut uji multikolinieritas dilihat dari nilai VIF nya, ketika nilainya VIF dibawah 10 maka model penelitian tidak terjadi masalah dan bisa dijelaskan.

Tabel 4. Uji Heterokedastisitas

\begin{tabular}{lllll}
\hline \multirow{2}{*}{ Model } & \multicolumn{2}{l}{ Unstand. Coeff } & T & Sig. \\
\cline { 2 - 3 } & B & Std. Er & & \\
\hline (Constant) & $-7,799$ & 2,240 & $-3,460$ & 0,001 \\
FDR & 0,023 & 0,017 & 1,387 & 0,167 \\
BOPO & 0,027 & 0,016 & 1,660 & 0,099 \\
Profit_Sharing & $-0,022$ & 0,100 & $-0,217$ & 0,829 \\
CAR & $-0,001$ & 0,026 & $-0,036$ & 0,971 \\
Kontribusi Sosial & 0,046 & 1,537 & 0,030 & 0,976 \\
\hline
\end{tabular}

Sumber: Hasil Pengolahan Data Sekunder, 2017

Sedangkan pada tabel 4 tersebut menginformasikan uji heterokedastisitas dengan menggunakan uji Park. Dan hasilnya nilai sig diatas 0,05 yang berarti tidak terdapat masalah heterokedastisitas pada penelitian ini. Oleh karena itu penelitian ini telah sesuai dengan persyaratan dalam uji asumsi klasik, sehingga dapat dilakukan pengujian selanjutnya.

\section{Uji Regresi}

Uji ini digunakan untuk mengetahui pengaruh parsial dan serentak dari variabel independen ke dependen. Pada penelitian ini menggunakan uji regresi berganda yang mana menggunakan dua pengukuran kinerja keuangan yakni ROA dan NOM. Selain itu juga akan menguji hubungan bolak balik antara Kinerja Keuangan dengan Kontribusi Sosial. Adapun untuk hasil pengujian ini adalah sebagai berikut: 
Tabel 5. Hasil Regresi Kinerja Keuangan (ROA)

\begin{tabular}{|c|c|c|c|c|c|}
\hline \multirow[t]{2}{*}{ Model } & \multicolumn{2}{|c|}{ Unstand. Coeff } & \multirow[t]{2}{*}{$\mathbf{T}$} & \multirow[t]{2}{*}{ Sig. } & \multirow[t]{2}{*}{ Keterangan } \\
\hline & B & Std. Er & & & \\
\hline (Constant) & 8,289 & 0,636 & 13,026 & 0,000 & \\
\hline FDR & $-0,001$ & 0,005 & $-0,290$ & 0,772 & Ditolak \\
\hline BOPO & $-0,082$ & 0,004 & $-19,661$ & 0,000 & Diterima \\
\hline PFR & 0,034 & 0,013 & 2,551 & 0,012 & Diterima \\
\hline CAR & $-0,002$ & 0,008 & $-0,297$ & 0,767 & Ditolak \\
\hline Adjusted $\mathrm{R}^{2}$ & \\
\hline $\mathrm{F}$ & \multicolumn{5}{|c|}{$107,179(\mathrm{P}-$ value $=0,000)$} \\
\hline $\mathrm{N}$ & \multicolumn{5}{|c|}{189} \\
\hline Variabel dependen & \multicolumn{5}{|c|}{ Kinerja Keuangan (ROA) } \\
\hline
\end{tabular}

Sumber: Hasil Pengolahan Data Sekunder, 2017

Tabel 6. Hasil Regresi Kinerja Keuangan (NOM)

\begin{tabular}{|c|c|c|c|c|c|}
\hline \multirow[t]{2}{*}{ Model } & \multicolumn{2}{|c|}{ Unstand. Coeff } & \multirow[t]{2}{*}{$\mathbf{T}$} & \multirow[t]{2}{*}{ Sig. } & \multirow[t]{2}{*}{ Keterangan } \\
\hline & $\mathbf{B}$ & Std. Er & & & \\
\hline (Constant) & 15,673 & 2,844 & 5,510 & 0,000 & \\
\hline FDR & $-0,022$ & 0,021 & $-1,0371$ & 0,301 & Ditolak \\
\hline BOPO & $-0,119$ & 0,019 & $-6,397$ & 0,000 & Diterima \\
\hline PFR & 0,179 & 0,059 & 3,047 & 0,003 & Diterima \\
\hline CAR & 0,016 & 0,034 & 0,484 & 0,629 & Ditolak \\
\hline Adjusted $\mathrm{R}^{2}$ & \multicolumn{5}{|l|}{$21,8 \%$} \\
\hline $\mathrm{F}$ & \multicolumn{5}{|c|}{$14,07(\mathrm{P}-$ value $=0,000)$} \\
\hline $\mathrm{N}$ & \multicolumn{5}{|l|}{189} \\
\hline Variabel dependen & \multicolumn{5}{|c|}{ Kinerja Keuangan (NOM) } \\
\hline
\end{tabular}

Untuk pengujian bolak-balik antara Kinerja Keuangan dengan Kontribusi Sosial adalah sebagai berikut:

Tabel 7. Hasil Uji Two-Stage Least Square

\begin{tabular}{|c|c|c|c|c|c|c|}
\hline \multirow[t]{2}{*}{ Model } & & \multicolumn{2}{|c|}{ Unstandard.Coefficients } & \multirow[t]{2}{*}{$\mathrm{T}$} & \multirow[t]{2}{*}{ Sig. } & \multirow[t]{2}{*}{ Keterangan } \\
\hline & & B & Std. Error & & & \\
\hline 1. & & $-14,787$ & 0,582 & $-25,386$ & 0,000 & \\
\hline & ROA & 57,994 & 2,116 & 27,409 & 0,000 & Diterima \\
\hline
\end{tabular}

Sumber : Hasil Pengolahan Data Sekunder, 2017

Tabel 4.8

Hasil Uji Two-Stage Least Square

\begin{tabular}{|c|c|c|c|c|c|c|}
\hline \multirow[t]{2}{*}{ Model } & & \multicolumn{2}{|c|}{ Unstandard.Coefficients } & \multirow[t]{2}{*}{$\mathrm{T}$} & \multirow[t]{2}{*}{ Sig. } & \multirow[t]{2}{*}{ Keterangan } \\
\hline & & B & Std. Error & & & \\
\hline 1. & NOM & $\begin{array}{l}-33,969 \\
141,099\end{array}$ & $\begin{array}{l}2,154 \\
7,823\end{array}$ & $\begin{array}{l}-15,773 \\
18,036\end{array}$ & $\begin{array}{l}0,000 \\
0,000\end{array}$ & Diterima \\
\hline
\end{tabular}

Sumber: Hasil Pengolahan Data Sekunder, 2017

Didapatkan hasil beberapa variabel yang digunakan mempunyai pengaruh pada kinerja keuangan dan variabel lainnya tidak memiliki pengaruh terhadap kinerja keuangan. Untuk variabel yang berpengaruh terhadap Kinerja Keuangan adalah Efisiensi Operasional, Prinsip Bagi Hasil dan Kontribusi Sosial. Sedangkan untuk variabel yang tidak memiliki pengaruh terhadap kinerja keuangan adalah pembiayaan dan kecukupan modal.

\section{Pengaruh Pembiayaan Terhadap Kinerja Keuangan}

Hasil pengujian hipotesis yang telah dilakukan menunjukkan variabel pembiayaan tidak memiliki pengaruh pada Kinerja Keuangan di Bank Umum Syariah. Hasil tersebut tidak bisa 
membuktikan teori Stewardship yang menyatakan bahwa para eksekutif pada suatu perusahaan bertindak sebagai pelayan yang termotivasi untuk menjalankan perusahaan dengan cara terbaik pada prinsipalnya (Donaldson dan Davis, 1991). Pada dasarnya pembiyaan perbankan syariah merupakan salah satu produk yang dihasilkan untuk menghasilkan laba. Skema pembiayaan bank syariah di Indonesia memang lebih dioptimalkan pada murabahah dibandingkan dengan mudharabah, musyarakah atau jenis pembiayaan lainnya. Hal ini dikuatkan dengan publikasi OJK yang menunjukkan pembiayaan yang disalurkan sebesar 93.642 milliar jauh lebih besar dibandingkan dengan musyarakah 47.357 milliar dan mudharabah 7.979 milliar pada tahun 2015. Akan tetapi jika dilihat dari nilai penerimaannya skema murabahah nilainya lebih kecil jika dibandingkan skema lainnya apabila dirata-rata. Oleh karena itu pembiayaan yang semakin meningkat apabila penerimaan yang didapat kecil akan mengakibatkan resiko pembiayaan bermasalah (NPF) tinggi, sehingga akan mengakibatkan kinerja keuangan turun.

\section{Pengaruh Efisiensi Operasional Terhadap Kinerja Keuangan Perbankan Syariah}

Hasil uji analisis pada hipotesis kedua membuktikan variabel efisiensi operasional memiliki pengaruh terhadap kinerja keuangan. Semakin meningkat efisiensi operasional perusahaan maka nilai BOPO nya semakin rendah sehingga kinerja keuangan mengalami peningkatan. Hasil tersebut membuktikan teori stewardship yang menyatakan para eksekutif pada suatu perusahaan bertindak sebagai pelayan yang termotivasi untuk menjalankan perusahaan dengan cara terbaik pada prinsipalnya (Donaldson dan Davis, 1991). Selain itu juga sesuai dengan penelitian dari Setiawan (2009) berkaitan BOPO terhadap profitabilitas perbankan syariah. Publikasi dari OJK menunjukkan pertumbuhan kinerja keuangan mengalami penurunan dari prosentase $2 \%$ menjadi $0 \%$. Sementara itu prosentase BOPO justru mengalami peningkatan dari $78 \%$ bertambah besar menjadi $96 \%$. Oleh karena itu hal tersebut membuktikan bahwasannya efisiensi operasional berpengaruh pada kinerja keuangan di Bank Umum Syariah di Indonesia.

\section{Pengaruh Prinsip Bagi Hasil Terhadap Kinerja Keuangan Perbankan Syariah}

Pada hasil pengujian untuk hipotesis ini membuktikan bahwa variabel prinsip bagi hasil memiliki pengaruh terhadap kinerja keuangan. Hasil ini membuktikan teori syariah enterprise theory yang menekankan dalam pelaksanaan usaha yang dijalankan untuk kepentingan stakeholder yang meliputi Allah, manusia dan alam (Triyuwono, 2007). Selain itu juga mendukung penelitian sebelumnya yang dilaksanakan oleh Falikhatun dan Umar (2012) menunjukkan Profit Sharing Financing Ratio berpengaruh terhadap kesehatan finansial di bank umum syariah yang di ukur dengan NOM. Semakin meningkat prinsip bagi hasil yang didapatkan perusahaan maka kinerja keuangannya juga akan semakin baik. Keterkaitan kedua variabel tersebut juga dibuktikan data lapangan dari laporan keuangan BNI Syariah tahun 2015 yang menunjukkan angka kinerja keuangan meningkat dari triwulan pertama hingga ke empat. Sementara itu profit sharing ratio juga mengalami peningkatan pada triwulan yang sama.

\section{Pengaruh Kecukupan Permodalan Terhadap Kinerja Keuangan di Perbankan Syariah}

Untuk hasil pengujian pada variabel kecukupan permodalan yang di ukur dengan CAR pada Kinerja Keuangan menunjukkan bahwa tidak memiliki pengaruh terhadap kinerja keuangan. Hasil pengujian tersebut tidak bisa membuktikan teori stewardship. Kecukupan permodalan dalam suatu perusahaan digunakan utnuk membiayai operasional perusahaan. Selain itu juga untuk menjamin masyarakat ketika berinvestasi di suatu perusahaan karena memiliki modal yang cukup dalam operasional sehari-hari. Para eksekutif di perbankan syariah dalam penyediaan kecukupan modal sebenarnya telah sesuai dengan standart regulasi yang sudah dipersyaratkan. Hal itu dapat dilihat dari Tabel 4.1 Statistik Deskriptif dengan nilai minimum CAR 9,5\% yang mana lebih besar dari standart yang telah ditentukan yakni $8 \%$. Akan tetapi data lapangan menunjukkan terjadinya kenaikan rasio pembiayaan bermasalan (NPF) dari 2,22\% (2012) ke 5,54\% (2016), jauh di atas NPF Bank Umum dari $1,87 \%$ (2012) ke 3,11\% (2016). Tingkat kenaikan pada angka NPF tersebut menunjukkan semakin tingginya aset beresiko yang dimiliki bank syariah dibandingkan permodalannya. Oleh karena itu kecukupan permodalan dalam perbankan syariah belum tentu mempengaruhi dalam meningkatkan kinerja keuangan pada bank umum syariah di Indonesia.

Pengaruh Kontribusi Sosial terhadap Kinerja Keuangan Perbankan Syariah 
Pada pengujian variabel kontribusi sosial terhadap kinerja keuangan menggunakan pengujian secara simultan. Adapun untuk hasilnya adalah menunjukkan kontribusi sosial secara simultan memiliki pengaruh terhadap kinerja keuangan di perbankan syariah. Kontribusi Sosial adalah implikasi dari CSR yang diberikan kepada masyarakat. Ketika Kontribusi Sosial yang dilaksanakan perbankan syariah tinggi, maka hal ini akan menarik bagi nasabah untuk berinvestasi sehingga akan meningkatkan kinerja keuangan. Hasil pengujian tersebut mendukung penelitian sebelumnya dari Mallin, Farag, dan OwYong (2014) terkait CSR dengan kinerja keuangan pada bank-bank Islam menunjukkan bukti empiris yang penting berkaitan hubungan positif antara CSR dan kinerja keuangan di bank-bank Islam. Adanya kontribusi sosial ini sebagai kontra prestasi atas peran langsung stakeholder dalam mengembangkan perusahaan. Semakin besar kontribusi sosial yang dihasilkan membuktikan semakin meningkat peranan yang diberikan oleh stakeholder kepada perusahaan sehingga diharapkan kinerja perusahaan semakin baik juga.

Sedangkan untuk hasil pengujian kinerja keuangan terhadap kontribusi sosial menunjukkan semakin meningkat kinerja keuangan maka diharapkan kontribusi sosialnya juga meningkat. Hal ini dikarenakan penerima kontribusi sosial adalah masyarakat yang mana besarannya berasal dari laba neto perusahaan dan denda dari nasabah bank syariah. Dengan demikian ketika kinerja keuangan yang dihasilkan oleh bank syariah tinggi maka seharusnya kontribusi sosial yang diberikan kepada masyarakat juga semakin besar. Akan tetapi hasil penelitian ini tidak sama dengan Rokhmana (2015) yang menemukan ROA tidak berpengaruh terhadap Qard Ratio sebagai ukuran Kontribusi Sosial. Dalam penelitian Rokhmana (2015) untuk pengukuran kontribusi sosialnya dengan menggunakan Qard Ratio dan Zakat Ratio. Sedangkan dalam penelitian ini untuk kontribusi sosialnya menggunakan pengukuran yang lebih luas yakni Rasio Pelaksanaan Fungsi Sosial (RFS), Rasio Kontribusi Kesejahteraan Sohibul Maal (KSM),Rasio Alokasi Kesejahteraan Mudharib (KM)dan Rasio Kontribusi Pajak untuk Pemerintah (KPP) sehingga dalam hasil pengujian yang didapatkan lebih komprehensif.

\section{SIMPULAN}

Penelitian ini menggunakan pendekatan kuantitatif yang berdasarkan pada kerangka penelitian, selanjutnya dilakukan pengujian atas faktor-faktor yang memiliki pengaruh pada kinerja keuangan di perbankan syariah. Untuk determinan dalam penelitian ini menggunakan variabel efisiensi operasional, kecukupan permodalan, pembiayaan, dan prinsip bagi hasil. Selain itu juga akan melakukan pengujian simultan antara kinerja keuangan dengan kontribusi sosial pada perbankan syariah di Indonesia periode 2012-2016. Data penelitian adalah Bank Umum Syariah (BUS) pada tahun 2012-2016. Selanjutnya data-data tersebut didapat 13 Bank Umum Syariah yang tercatat, kemudian diambil secara triwulanan dan akhirnya didapatkan sejumlah 189 data triwulanan. Setelah dilakukan analisis pengujian, hasilnya bahwa variabel efisiensi operasional, prinsip bagi hasil dan kontribusi sosial berpengaruh pada kinerja keuangan. Sedangkan untuk variabel pembiayaan dan kecukupan permodalan tidak memiliki pengaruh pada kinerja keuangan bank syariah Indonesia.

Berdasarkan hasil temuan dalam penelitian ini, juga masih terdapat keterbatasan-keterbatasan yang bisa diperbaiki dan diteliti kembali untuk peneliti selanjutnya, diantaranya variabel untuk kinerja sosial yang digunakan hanya kontribusi sosial, sehingga belum mencakup semua pengukuran dalam kinerja sosial menurut Stiawan (2009). Selain itu periode waktu yang digunakan dalam penelitian ini saat bank syariah mengalami penurunan. Pada periode-periode sebelumnya tidak diikutkan padahal periode tersebut bank syariah sedang mengalami kenaikan, sehingga belum menghasilkan faktor-faktor yang mempengaruhi kinerja keuangan bank syariah secara komprehensif. Oleh karena itu berdasarkan temuan keterbatasan tersebut dapat digunakan sebagai acuan dalam penelitian selanjutnya.

\section{DAFTAR PUSTAKA}

Abdullah, W.A., Percy, M., dan Stewart, J., "Shari'ah disclosures in Malaysian and Indonesian Islamic banks". Journal of Islamic Accounting and Business Research, Vol. 4, No.2, pp.100-131

Ascarya. 2007. Akad dan Produk Bank Syariah. Jakarta: PT. Rajagrafindo Persada

Almilia dan herdaningtyas. 2005. "Analisis rasio camel terhadap prediksi kondisi bermasalah pada lembaga perbankan 2000-2002". Jurnal Akuntansi dan keuangan,vol 7, no.2.

Antonio, M.S. 2001. Bank Syariah: Dari Teori ke Praktik. Jakarta: Gema Insani Press. 
Dendawijaya, Lukman. 2005. Manajemen Perbankan (Edisi Pertama). Bogor: Ghalia Indonesia.

Donaldson, L. dan Davis, J. 1991. "Stewardship Theory or Agency Theory: CEO Governance and Shareholder Returns". Australian Journal of Management, Vol. 16, issue 1, pp. 49-64

Eka, L. 2014. "Studi Mengenai Pengaruh Financing to Deposit Ratio, Net Operating Margin dan Credit Risk Terhadap Kinerja Keuangan Pada Bank Syariah di Indonesia". Tesis Tidak Dipublikasikan, Program Studi Magister Akuntansi, Universitas Diponegoro

Fadila, Ihda. 2016. “Kinerja Syariah Kedodoran”Harian Bisnis Indonesia, 2 Agustus 2016, online

Falikhatun dan Umar. 2012. "Bank Syariah Di Indonesia: Ketaatan Pada Prinsip Syariah dan Kesehatan Finansial". Proccedings of conference in Business, Accounting, and Management (CBMA) 2012, Vol. 1 No. 1 Desember. Hal 245-254.

Ghozali, I. 2006. Analisis Multivariate Lanjutan Dengan Program SPSS. Semarang: Badan Penerbit Universitas Diponegoro

Ghozali, I. 2007. Aplikasi Analisis Multivariate Dengan Program SPSS. Semarang: Badan Penerbit Universitas Diponegoro

Hameed, S., Wirman, A., Alrazi, Nazli, Pramono. 2004. "Alternative Disclosure \& Performence Measures for Islamic Bank". Journal International Islamic University Malaysia

Hasanah, U. 2015. "Kepatuhan Prinsip-Prinsip Syariah dan Islamic Corporate Governance Terhadap Kesehatan Finansial Pada Bank Umum Syariah". Journal Universitas Negeri Semarang

Ichsan, R. 2013. “Teori Keagenan (Agency Theory)”, Islam, Ekonomi, Indonesia

https://bungrandhy.wordpress.com. Diakses tanggal 24 Februari 2017

Imam. 2007. "Pengaruh CAR, FDR, BOPO dan NPL Terhadap Profitabilitas Bank Syariah Mandiri Periode Tahun 2004-2006”. Tesis Tidak Dipublikasikan, Universitas Islam Indonesia

Islamic Financial Services Board, 2015, Islamic Financial Services Industry Stability Report 2009-2013, Kuala Lumpur

Islamic Financial Services Board, 2016, Islamic Financial Services Industry Stability Report 2009-2014, Kuala Lumpur

Jatnika, Firman. 2016. "Peta Baru Bank Syariah"Harian Republika E-Paper, 19 Juli 2017, online

Jensen, M. dan Meckling, W. 1976. "Theory of the Firm: Managerial Behavior,

Agency Costs and Ownership Structure”. Journal of Financial Economics, No. 4 Volume 3, pp. 305360

Junita, S. 2015. "Pengaruh KAP, BOPO dan FDR Terhadap Net Operating Margin.”, Journal UIN Syarif Hidayutullah, Vol. 11, No. 5, pp. 1-16

Kasmir. 2005. Bank dan lembaga keuangan lain. PT. Raja Grafindo Perkasa Edisi 6, Jakarta.

Karim, Adiwarman A. 2010. Bank Islam :Analisis Fiqih dan Keuangan (Edisi 4).

Jakarta: PT. Rajagrafindo Persada

Khan, Tariqulla dan Ahmad (2001). Risk Management on Analysis of Issues in Islamic Financial Industry. Islamic Research and Training Institute : Islamic Development Bank

Mallin, C., Farag, H., Ow-Yong, Kean. 2014. "Corporate Social responsibility and financial performance in Islamic banks". Journal of Economic behavior \& Organization, Vol. S21-S38, No. 103 , pp. 1-18 